\title{
Natural compounds as potential algaecides for waterborne paints
}

\author{
Sandra G. Gómez de Saravia, Silvia E. Rastelli, Guillermo Blustein, Marisa R. Viera
}

(C) American Coatings Association 2018

\begin{abstract}
To eliminate and prevent the formation of phototrophic biofilms on painted walls, chemicals are added to paints. These chemicals, in general, also have toxic effects on the environment. Plants synthesize secondary metabolites which have antimicrobial properties and that may be a sustainable alternative to traditional biocides. In this work, algal species isolated from biofilms formed on deteriorated painted surfaces were taxonomically identified. Observations with the optical microscope revealed the presence of mixed biofilms composed of algae belonging to the Cyanophyta, Chlorophyta, and Streptophyta divisions. The algaecide effect of natural compounds of vegetal origin such as anisole, eugenol, guaiacol, and thymol was evaluated by the microatmosphere technique. Growth inhibition of phototrophic organisms was obtained with thymol in all the concentrations used. Eugenol and guaiacol showed a total growth inhibition at the highest concentration assayed $\left(300 \mu \mathrm{mol} \mathrm{cm}{ }^{-2}\right)$ and a decrease in growth at $40 \mu \mathrm{mol} \mathrm{cm}{ }^{-2}$, while anisole did not exert any inhibitory action at the assayed concentrations. Due to these results, eugenol, thymol, and guaiacol
\end{abstract}

S. G. Gómez de Saravia ( $₫)$, S. E. Rastelli,

G. Blustein, M. R. Viera

Centro de Investigación y Desarrollo en Tecnologías de

Pinturas (CIDEPINT), (CICPBA-CONICET), 52 e/121 y

122 (1900), La Plata, Buenos Aires, Argentina

e-mail: s.gomez@cidepint.gov.ar

S. G. Gómez de Saravia, S. E. Rastelli

Facultad de Ciencias Naturales y Museo, UNLP, La Plata,

Argentina

G. Blustein

Facultad de Ciencias Agrarias y Forestales, UNLP, La

Plata, Argentina

M. R. Viera

Facultad de Ciencias Exactas, UNLP, La Plata, Argentina were incorporated in an exterior waterborne paint at a concentration of $2 \%$. Samples painted with these formulations were not colonized by algae, indicating that these compounds could be used as biocides in paint formulations.

Keywords Natural organic compounds, Biocide, Algaecide, Waterborne paint, Phototrophic biofilm

\section{Introduction}

Phototrophic organisms, such as cyanobacteria and algae, can flourish without recourse to organic nutrients and are found in the majority of external paint biofilms. ${ }^{1}$ Their growth on the external surfaces of buildings can cause discoloration and physicochemical deterioration. $^{2}$

Some authors suggested that bacteria were the primary colonizers, ${ }^{3}$ while others proposed phototrophic microorganisms for this role. ${ }^{1}$ Phototrophic biofilms proliferate especially in walls where atmospheric humidity is high $^{4}$ as in La Plata city (Buenos Aires, Argentina), ${ }^{5}$ where this study was conducted. These processes have increased significantly, especially in urban areas, due to increasing environmental pollution. Several chemical compounds present in the polluted atmosphere, such as sulfate, nitrate, and ammonia, are nutrients for algae..$^{6,7}$

The Cyanophyta (green-blue algae) and Chlorophyta (green algae) are the most abundant phototrophic organisms colonizing facades and building stones. ${ }^{8}$ The high resistance of Cyanophyta to UV light is associated with the production of protective pigments; these pigments are responsible for the aesthetic deterioration of building painted surfaces varying in color from greenish-yellow to dark green and black and from rosy to gray and brown, according to the characteristics of the taxa. ${ }^{9}$ 

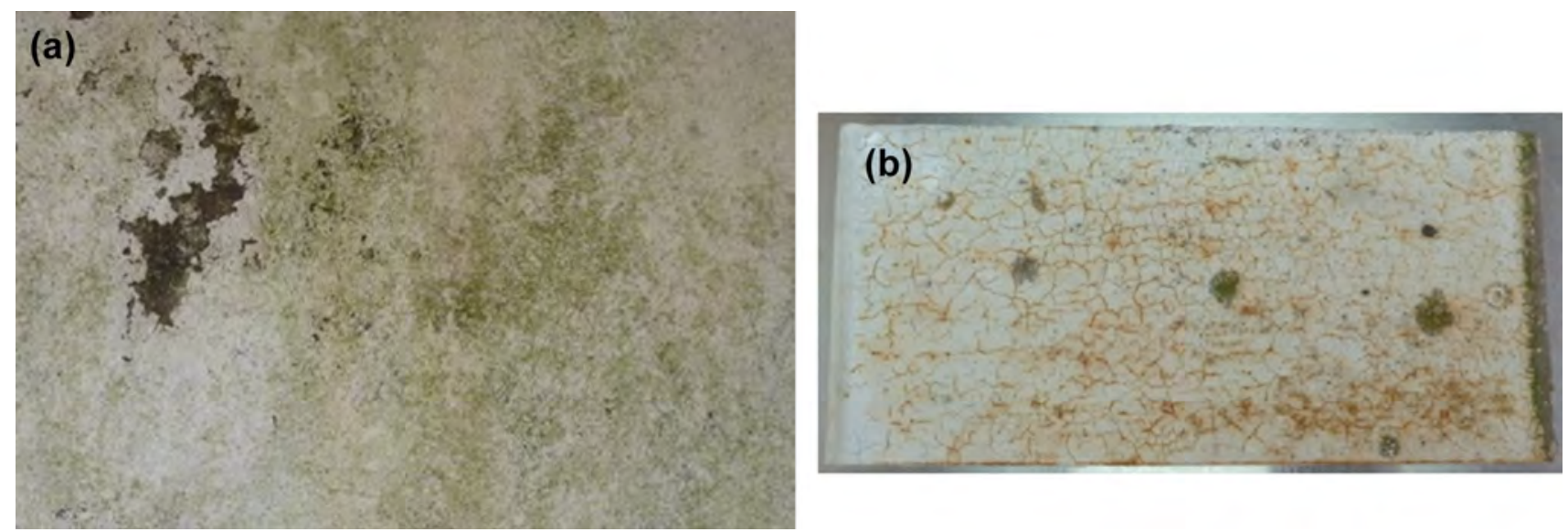

Fig. 1: General aspect of the sources of the algae used in the present work: (a) exterior wall (sample R) and (b) metallic painted panel (sample P)

Various biocides are commonly added to exterior and interior paint formulations to provide protection of the dry films against fungal and algal growth. Besides, some products are added as bactericides and as in-can preservatives. In summary, paints could contain about $0.5-1 \%$ of a mixture of one to eight different biocides. ${ }^{10}$ Triazines and phenylureas are used as algaecides and carbamates as fungicides, while isothiazolinones are used as bactericides in paint formulations for such purposes. Besides the use as film preservatives, some of the biocides are only added as in-can preservatives to increase shelf life of the formulated products until they are used. ${ }^{11}$ These biocides can be leached from the materials if rainwater comes into contact with these buildings, this being one of the major sources of biocide pollution concerning urban waters. ${ }^{12}$ Because of this, more environmentally friendly ecotoxicological compounds are being sought. In this way, the use of chemicals derived from natural compounds or extracted from live organisms seems to be an interesting substitute to traditional algaecides. ${ }^{13}$

Both essential oils from plants and their individual components have been extensively studied because they display a broad spectrum of antimicrobial activities. ${ }^{14}$ Besides, as they present little or no toxicity to aquatic animals and humans and they are biodegraded in natural environment, ${ }^{15}$ they could be a sustainable alternative to traditional biocides in paint formulations. Thymol, eugenol, anisole, and guaiacol are phenolic compounds that occur in essential oils isolated from herbs and spices and exhibit antibacterial and antifungal properties. ${ }^{16,18}$ Although these compounds were used to formulate different antimicrobial coatings for food and pharmaceutic industries, ${ }^{18-20}$ there are few papers that refer to the use of these compounds as algaecide in paints. ${ }^{21}$

The aim of the present study was to evaluate the algaecide effect of natural organic products on different algae isolated from phototrophic biofilms formed on painted walls of urban environments and to test the performance of waterborne paints formulated with those substances which have exhibited good algaecide activity.

\section{Materials and methods}

\section{Source of algae}

Samples of flaking paint from two surfaces showing colonization and biodeterioration signs were taken. One of them was taken from an exterior wall (sample R), with south-southeast orientation, surrounded by abundant vegetation that kept the wall wet and dark. The other sample was taken from a metallic panel exposed to the weather (sample P) on a terrace, with a high incidence of sunlight (Fig. 1). In both cases, flakes were collected by scraping using sterile tweezers and scalpel. The material was placed in physiological solution and transported to the laboratory.

\section{Taxonomic determination of algae and isolation of algal taxa}

Biological material was detached from the paint flakes using a sterile scalpel and was used for taxonomic determination and isolation of the algae present in the biofilms. The scrapped material was transferred to BG11 broth medium ${ }^{22}$ for maintenance of the algae communities. In order to isolate single microalgal species from the samples, standard plating methods were used: $200 \mu \mathrm{L}$ of the cultures was seeded in BG11 agar plates, incubated under controlled photoperiod conditions (16-/8-h light/darkness) and $25^{\circ} \mathrm{C}$. Different algal cells were picked from the plates and seeded in new plates for isolation. Identification of the taxa of the organisms present in the samples to the genus level was based on the morphology of the individual cells following microscopic examination and the use of 
Table 1: Characteristics of the natural organic compounds assayed

\begin{tabular}{|c|c|c|}
\hline Compound & $\begin{array}{l}\text { Formula and chemical } \\
\text { structure }\end{array}$ & Characteristics \\
\hline Anisole & $\mathrm{CH}_{3} \mathrm{OC}_{6} \mathrm{H}_{5}$ & $\begin{array}{l}\text { Liquid, colorless, with a similar odor to anise seeds. Many of its byproducts are found in } \\
\text { natural and artificial fragrances }\end{array}$ \\
\hline Guaiacol & $\mathrm{C}_{6} \mathrm{H}_{4}(\mathrm{OH})\left(\mathrm{OCH}_{3}\right)$ & $\begin{array}{l}\text { Yellowish aromatic oil derived mainly from guaiac (Guaiacum officinale). Precursor of } \\
\text { diverse artificial flavorings (eugenol, vanilla) }\end{array}$ \\
\hline Eugenol & $\mathrm{C}_{10} \mathrm{H}_{1}$ & $\begin{array}{l}\text { Derived from guaiacol with an allyl chain substituted. Pale yellow oily liquid extracted } \\
\text { from essential oils, such as clove, nutmeg, cinnamon, laurel, basil, and pennyroyal. It } \\
\text { is used in odontology as dental cement }\end{array}$ \\
\hline Thymol & $\mathrm{C}_{10} \mathrm{H}_{14} \mathrm{O}$ & $\begin{array}{l}\text { Crystalline colorless substance with a characteristic odor. It is present in essential oils } \\
\text { of thyme (Thymus vulgaris) or oregano (Origanum majorana). It has disinfectant and } \\
\text { fungicide power }\end{array}$ \\
\hline
\end{tabular}

literature data. ${ }^{23-25}$ Both algae communities and isolated taxa were used in the biocide activity tests.

\section{Microscopic observations}

Characteristics of the phototropic biofilms and of the isolated taxa were assessed using optic microscopy (OM) (Arcano, China), epifluorescence microscopy (EM) (Olympus BX51, Olympus, Japan), and scanning electron microscopy (SEM) (FEI Quanta 200, Thermo Fisher, USA). Samples did not require any treatment for observation by OM or EM. On the contrary, prior to SEM observations, the material was fixed in $2.5 \% \mathrm{v} /$ $\mathrm{v}$ glutaraldehyde in phosphate-buffered saline (PBS) and metalized with Au.

\section{Natural organic compounds}

The algaecide properties of four pure compounds (Sigma-Aldrich, USA) which can be obtained from plants were evaluated. Table 1 shows some characteristics of these compounds.

\section{Algaecide activity tests}

\section{Microatmosphere test}

Considering that the compounds of interest are volatile substances, the microatmosphere test was used to evaluate their algaecide activity. ${ }^{26}$ For this, $200 \mu \mathrm{L}$ of a 7-day-old algae culture containing $\approx 1.2 \times 10^{5}$ algae $\mathrm{mL}^{-1}$ was inoculated uniformly in a Petri dish with BG11 agar. The number of cells was determined using a Neubauer haemocytometer. A sterile disk of filter paper $(13 \mathrm{~mm})$ was placed on the center of the inverted Petri dish lid and loaded with $50 \mu \mathrm{L}$ of the pure tested compound or a dilution in DMSO. The Petri dish was then hermitically sealed using Parafilm $\mathrm{M}^{\circledR}$ (Bemis Company Inc, USA) and incubated under controlled photoperiod conditions (16-/8-h light/darkness) and $25^{\circ} \mathrm{C}$ for 28 days. Partial results were 
Table 2: Base paint composition

Components

$\% \mathrm{w} / \mathrm{w}$

Additives

Oil-based silicone-free defoamer (THYOSIL Q202)

0.2

Hydroxyethyl cellulose (Cellosize 52,000)

0.5

Polyacrylic dispersing agent (Polacril D40)

0.3

2-amino-2-methyl-1-propanol (AMP-95)

0.1

Nonionic defoaming surfactant (TRITON ${ }^{\mathrm{TM}}$ CF-10) 0.1

Sodium hexametaphosphate

0.1

Pigments

Titanium dioxide

6.1

Natural calcium carbonate

20.0

Precipitated calcium carbonate

Resins

Acrylic emulsion (THYOSIL E 190)

37.0

Acrylic emulsion (THYOSIL E 195)

Solvents

Water

recorded weekly. Growth control plates were made without filter paper and with filter paper moistened with DMSO to remove inhibition of the algal growth due to the solvent. All the tests were performed in duplicate.

\section{Formulation, manufacture, and application of waterborne coatings}

An exterior white acrylic waterborne paint was formulated, as listed in Table 2. Base paint was prepared using a high-speed disperser at laboratory scale. Then, it was filtered and fractionated in four portions, one of which was used as a negative control and the remaining as treatments. Pigment volume concentration (PVC) was $57.7 \%$ for all paints tested. For treatments, the compounds that exhibited algaecide activity (eugenol, guaiacol, and thymol) were incorporated separately into the base paint $(2 \% \mathrm{w} / \mathrm{w})$. The paints were applied by brushing on specimens of filter paper. After applying three coats of paint, painted specimens were left to dry for 7 days in laboratory environment. Once dry, the samples were cut into squares $(2.8 \mathrm{~cm}$ side $)$ for bioassays. The presence of the different compounds in the formulation was monitored by ATR-FTIR using a Spectrum One spectrometer (PerkinElmer, USA).

\section{Algaecide activity of waterborne paints}

Samples of painted filter paper were inoculated in spray form with the phototrophic communities obtained from samples $\mathrm{R}$ and $\mathrm{P}$ or the isolated taxa given an initial number of approximately $4.2 \times 10^{5}$ algae $\mathrm{mL}^{-1}$. The samples were placed in Petri dishes with BG11 agar and incubated under controlled photoperiod conditions (16-/8-h light/darkness) and $25^{\circ} \mathrm{C}$ for 28 days. Partial results were recorded weekly. These tests were performed in triplicate.

\section{Results and discussion}

\section{Taxonomic determination of algae in the sampled biofilms}

The presence of algae is common in walls exposed to conditions of high humidity and illumination. The observations using the OM revealed that both sampled biofilms ( $\mathrm{R}$ and $\mathrm{P}$ ) consisted mainly of phototrophic organisms of diverse genera, though amebas and fungal hyphae were also identified in a lower amount. The biofilm formed on the exterior wall (R) showed a higher richness of species than the biofilm formed on the metallic surface (P). In Fig. 2, it is possible to distinguish some of the organisms presented in both samples as shown by the different microscopic techniques used. SEM observations of the biofilms revealed the presence of algae embedded in abundant extracellular polymeric substances (EPS). Taxa of the algae presented in the biofilms are listed in Table 3. Organisms belonging to the Cyanophyta, Chlorophyta, and Streptophyta divisions were found. Some of these organisms were reported in previous works, both in Latin America and in Europe. ${ }^{3}$ In both samples, Klebsormidium sp. aff. K. fluitans was predominant, and Chlorococcum sp. was also found in high numbers. In the case of sample R, Cyanophyta of the Chroococcales order were found among the most abundant organisms including Chroococcus sp. aff. C. varius. Chroococcus is one of the most widespread genera, and it was commonly reported on historic monuments, 
(a)

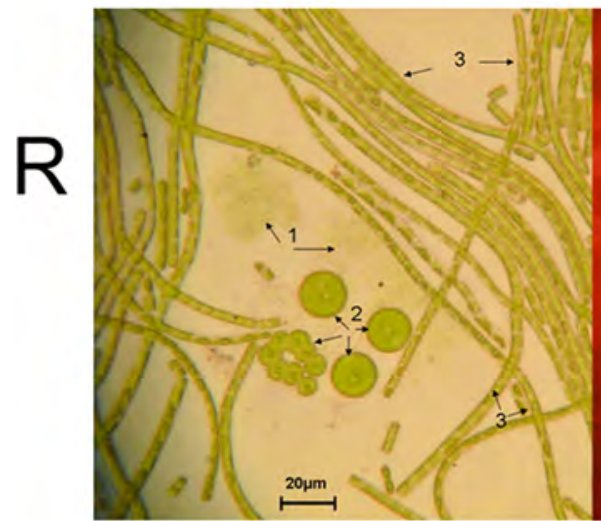

(b)

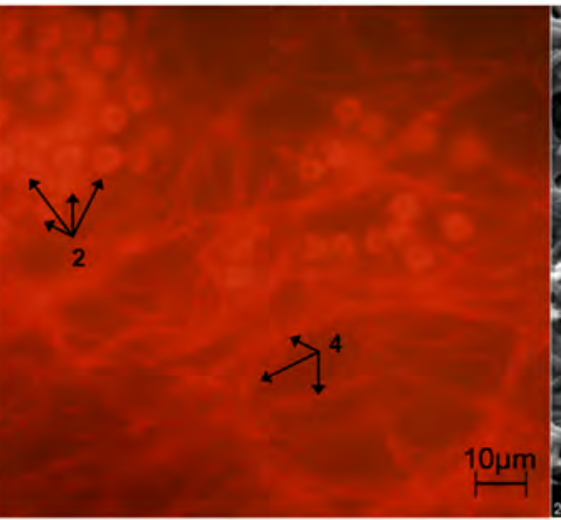

(c)

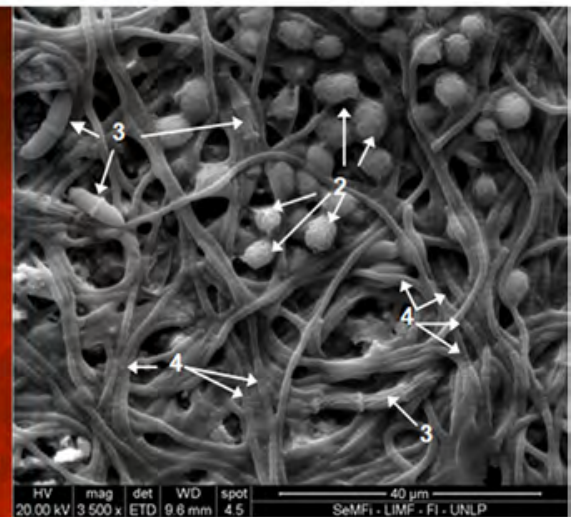

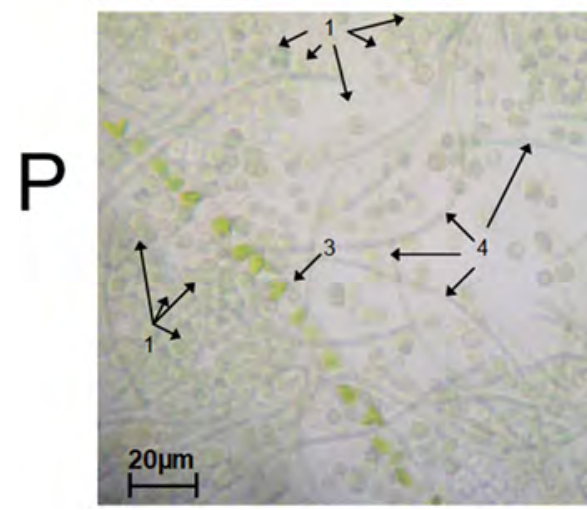
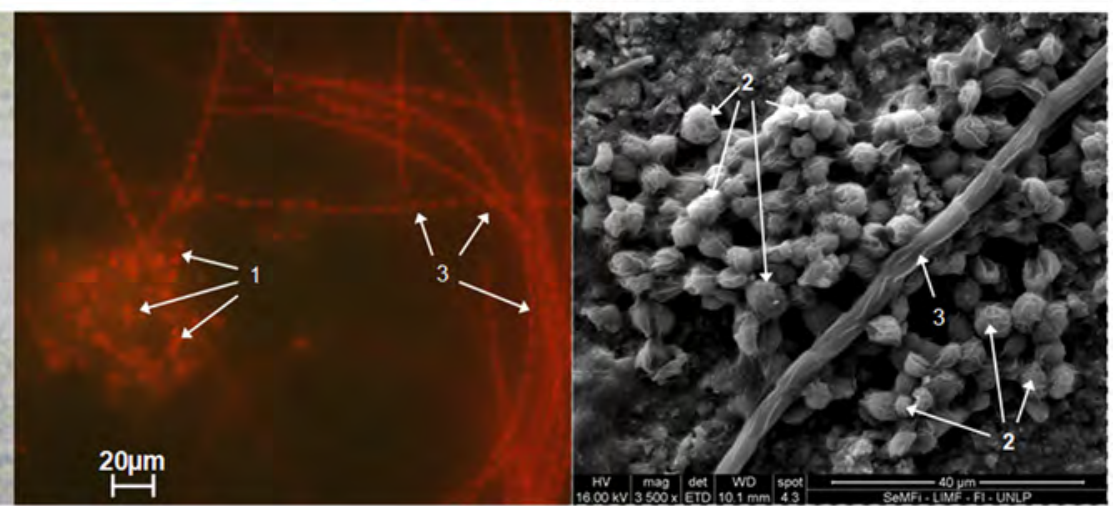

Fig. 2: Micrographs of the biofilms scraped from the samples: upper: $\boldsymbol{R}$ biofilm (exterior wall); lower: $P$ biofilm (metallic panel); 1: Xenococcaceae spp, 2: Chlorococcum sp, 3: Klebsormidium sp. aff. K. fluitans, 4: Leptolyngbya sp. aff. L. compacta. Photographs taken with: (a) optic microscope (bar: $20 \mu \mathrm{m}$ ), (b) epifluorescence microscope (upper bar: $10 \mu \mathrm{m}$, lower bar: $20 \mu \mathrm{m}$ ); (c) scanning electron microscope (bar: $40 \mu \mathrm{m}$ )

Table 3: Algal taxa determined in the biofilms and their estimated frequency

\begin{tabular}{|c|c|c|c|c|}
\hline \multirow[t]{2}{*}{ Division } & \multirow[t]{2}{*}{ Order } & \multirow[t]{2}{*}{ Taxa } & \multicolumn{2}{|c|}{ Frequency } \\
\hline & & & Biofilm $R$ & Biofilm $P$ \\
\hline \multirow[t]{7}{*}{ Cyanophyta } & Chroococcales & Xenococcaceae spp. & Predominant & - \\
\hline & & Chroococcus sp. aff. C.varius & Frequent & - \\
\hline & & Aphanocapsa sp. & Frequent & Frequent \\
\hline & & Pseudocapsa sp. aff. P.dubia & Frequent & - \\
\hline & & Aphanothece sp & Common & - \\
\hline & & Rhabdogloea sp & Common & - \\
\hline & Oscillatoriales & $\begin{array}{l}\text { Leptolyngbya sp. aff. } \\
\text { L. compacta }\end{array}$ & Scarce & Scarce \\
\hline \multirow[t]{3}{*}{ Chlorophyta } & Chlamydomonadales & Chlorococcum sp. & Frequent & Frequent \\
\hline & Chorellales & aff. Chorella sp & - & Scarce \\
\hline & & Apatococcus lobatus & - & Frequent \\
\hline Streptophyta & Klebsormidiales & $\begin{array}{l}\text { Klebsormidium sp. aff. } \\
\text { K. fluitans }\end{array}$ & Predominant & Predominant \\
\hline
\end{tabular}

Predominant: $\geq 50 \%$; frequent: $\approx 20 \%$; common: $5-15 \%$; scarce: $\leq 5 \%$; rare: $<0.5 \%$

contributing to their decay. ${ }^{27}$ Species isolated from both samples are shown in Fig. 3. Klebsormidium sp. aff. $K$. fluitans is a cylindrical filamentous alga, unis- eriate, unbranched, consisting of uninucleate cells 5$10 \mu \mathrm{m}$ wide by $15-20 \mu \mathrm{m}$ long. Chlorococcum sp. is a spherical green alga, of variable size, uninucleated; 
(a)
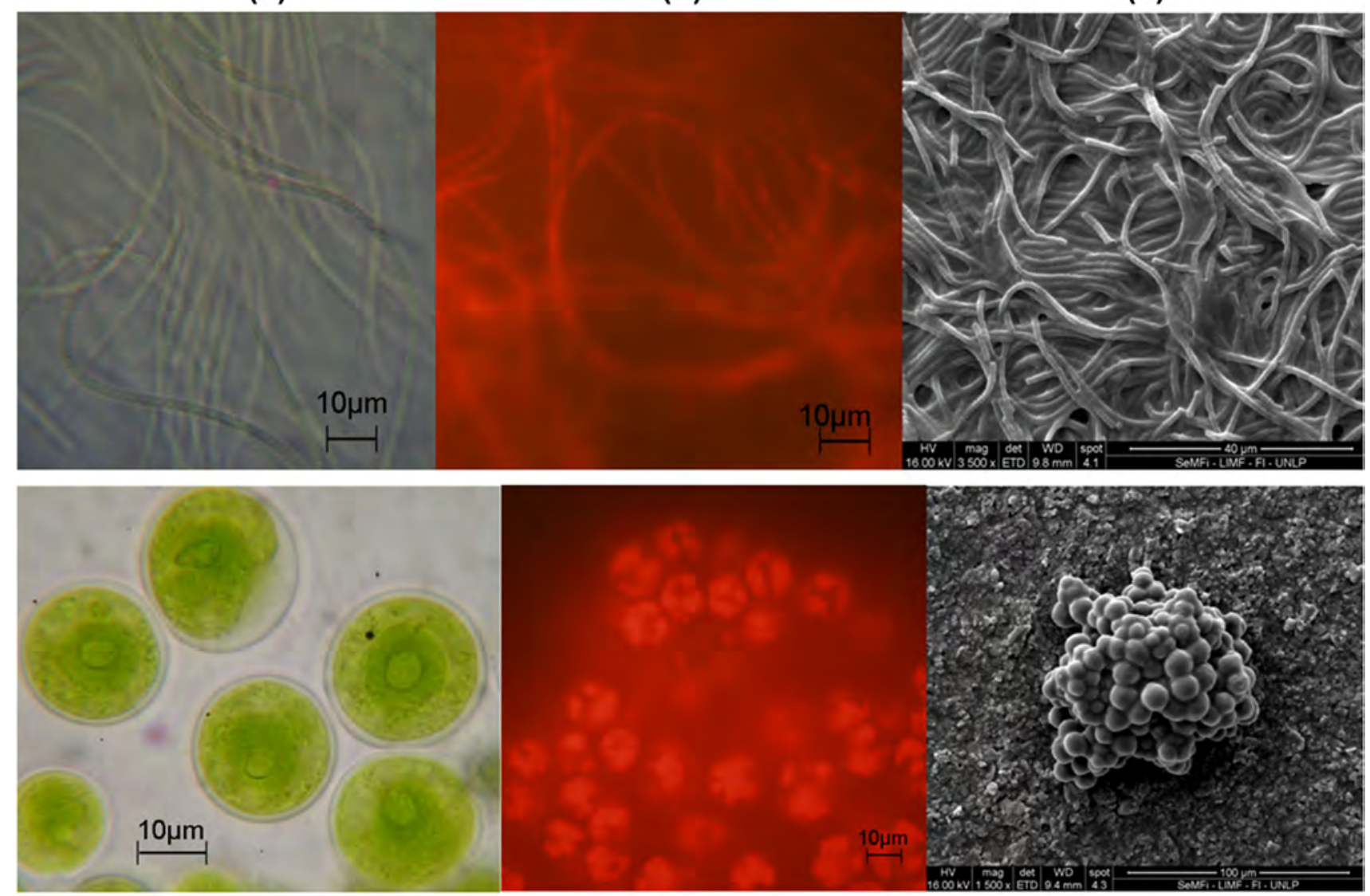

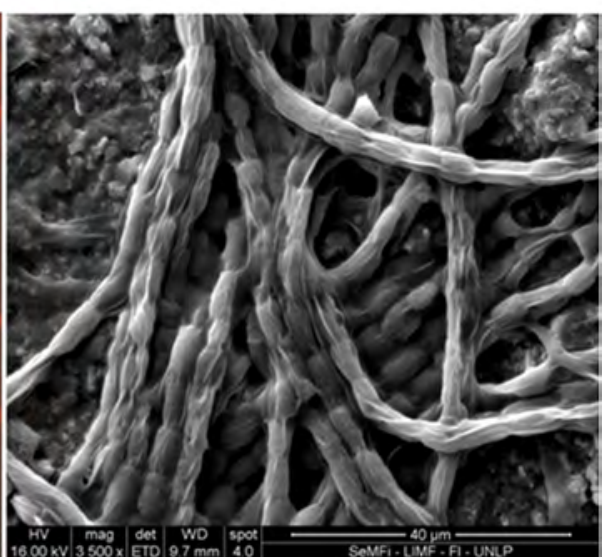

Fig. 3: Micrographs of the different taxa isolated from the biofilms. Upper row: Leptolyngbya sp. aff. L. compacta (Oscillatoriales, Cyanophyta). Middle row: Chlorococcum sp. (Chlorococcales, Chlorophyta). Lower row: Klebsormidium sp. aff. K. fluitans (Klebsormidiales, Streptophyta). (a) Optic microscope (bar: $10 \mu \mathrm{m}$ ), (b) epifluorescence microscope (bar: $10 \mu \mathrm{m}$ ), (c) scanning electron microscope (upper and lower bar: $40 \mu \mathrm{m}$; middle bar: $100 \mu \mathrm{m}$ )

these cells can be solitary or in groups not imbedded in sheath. Leptolyngbya sp. aff. L. compacta is a filamentous blue-green alga, uniseriate, consisting of isodiametric cells of 1.5-2 $\mu \mathrm{m}$ wide. Chroococcus sp. aff. $C$. varius is a espherical, subespherical or oval alga of 2$5 \mu \mathrm{m}$ diameter; they are solitary or in small groups of 2-4 cells surrounded by a mucilage or colorless gelatinous sheath.

\section{Algaecide tests}

\section{Microatmosphere test}

In the microatmosphere test, the inhibitory effect of the four compounds was quantified according to the coverage of the algal growth in the plates. The first experiments were performed with the pure compounds 


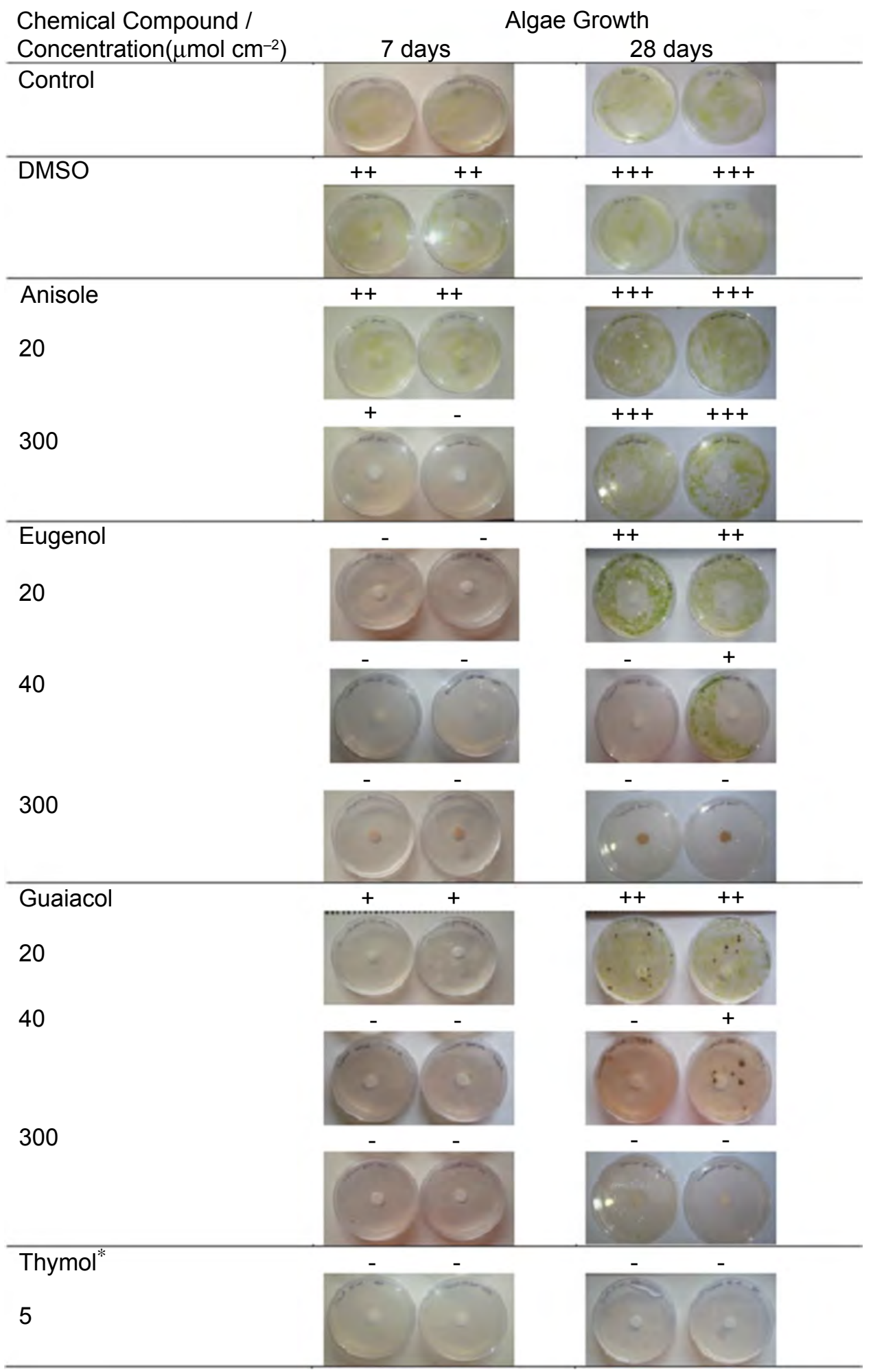

Fig. 4: Results of the microatmosphere tests obtained after exposing the algae community to different concentrations of the tested compounds during 7 and 28 days. -: no growth; +: $40-50 \%$ coverage; ++: $60-70 \%$ coverage; +++: $80-90 \%$ coverage. *Plates with the lowest concentration of thymol $\left(5 \mu \mathrm{mol} \mathrm{cm}{ }^{-2}\right)$ are shown

(400 $\mu \mathrm{mol}$ rendering a concentration in the filter

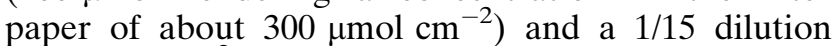
$\left(20 \mu \mathrm{mol} \mathrm{cm}^{-2}\right)$. Anisole did not exhibit any inhibitory effect on algal growth in these conditions; thus, it was discarded from further assays. On the contrary, eugenol, guaiacol, and thymol exhibited different 


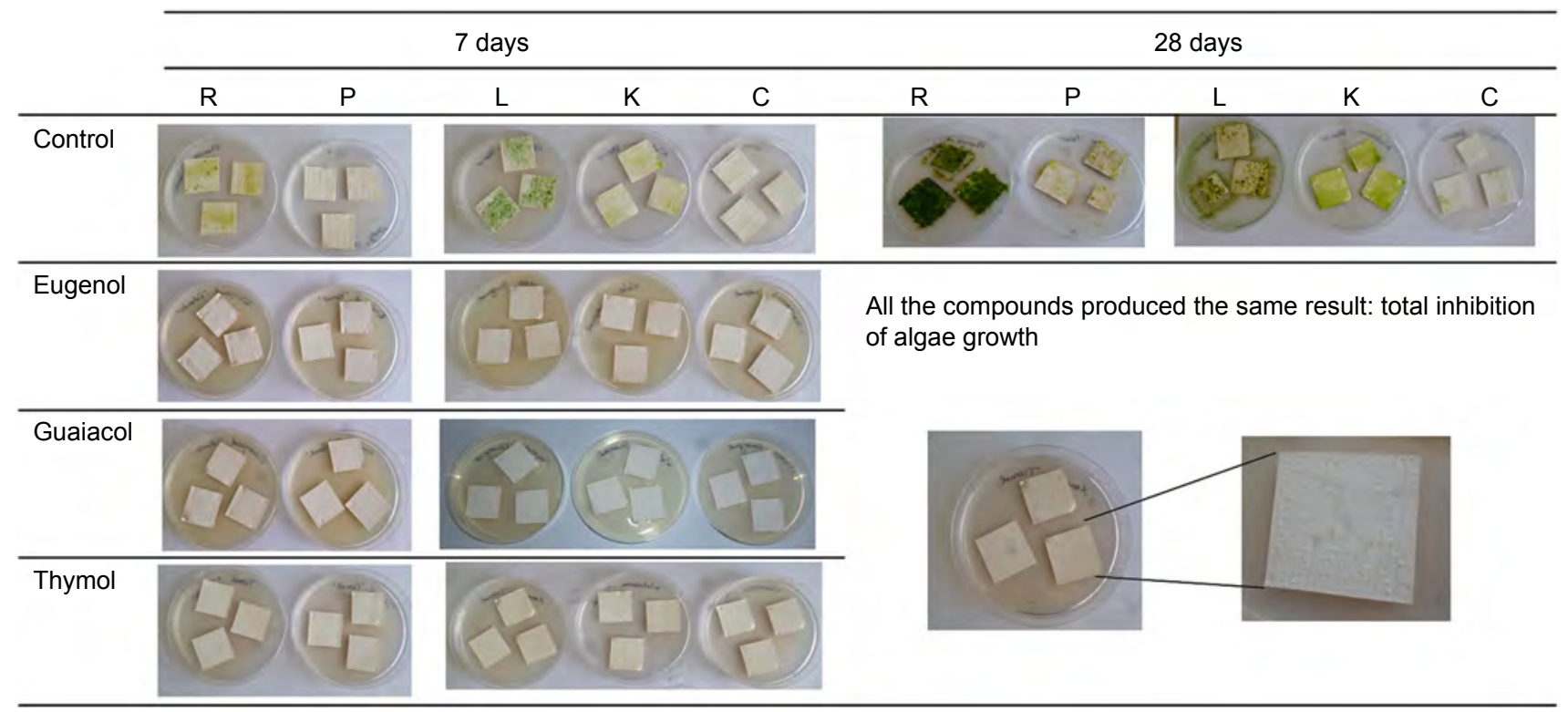

Fig. 5: Results of the incubation of the filter papers painted with the control paint or paints with $2 \%$ of the biocide in plates inoculated with different algae: $R=$ "R" community; $P=$ "P" community; $L=$ Leptolyngbia sp. aff. L. compacta; $\mathrm{K}=$ Klebsormidium sp. aff. K. fluitans; $\mathrm{C}=$ Clorococcum sp

degrees of growth inhibition, so they were tested in other concentrations. Thymol was effective up to a $1 / 60$ dilution, which means a concentration of $5 \mu \mathrm{mol} \mathrm{cm} \mathrm{cm}^{-2}$ in the filter paper, while the lowest effective concentration found for eugenol and guaiacol was $40 \mu \mathrm{mol}$ $\mathrm{cm}^{-2}$. Figure 4 summarizes the results obtained in the microatmosphere test after 7 and 28 days of exposure of the algae to the pure compounds and their dilutions. Several studies referred to thymol as a compound with biocide effect on a wide range of organisms including bacteria, lichens, fungi, larvae of insects, and mite. ${ }^{28} \mathrm{In}$ agreement with these studies, thymol was observed to be the most effective algaecide, exerting a total inhibition of algae growth in all the concentrations assessed from 5 to $300 \mu \mathrm{mol} \mathrm{cm}-2$. Bactericidal activity of thymol is mostly attributed to the action of its phenolic structure. It is well documented that thymol acts on the cytoplasmic membrane producing its structural disorganization leading to a failure in cellular permeability. ${ }^{29}$ Eugenol and guaiacol showed a total growth inhibition at the highest concentration assayed $(300 \mu \mathrm{mol} \mathrm{cm}-2)$, while lower concentrations (20 and $40 \mu \mathrm{mol} \mathrm{cm}{ }^{-2}$ ) allowed a low algal growth. Eugenol is a wide-spectrum antimicrobial, mainly against Gram-positive bacteria ${ }^{30}$; it also has antifungal properties. ${ }^{14}$ Like thymol, the cytoplasmic membrane is the target site of the eugenol molecule. However, unlike thymol, eugenol interferes with the active sites of acidic permeases. ${ }^{31,32}$

Several authors have found changes in the shape and structure of spores of fungi and changes in the shape, size, and color of the algae exposed to different chemical compounds including eugenol. ${ }^{33,34}$ Although our results indicate a reduction in algae growth in the presence of 20 and $40 \mu \mathrm{mol} \mathrm{cm} \mathrm{cm}^{-2}$ of this compound, no changes in the morphology of the algae were observed. Regarding anisole, variable results were reported. This compound presents low fungicide effectivity. ${ }^{30}$ According to our results, anisole did not present total or partial inhibitory effects on algal growth even when applied pure $\left(300 \mu \mathrm{mol} \mathrm{cm}{ }^{-2}\right)$.

\section{Algaecide effect of paints with the natural products incorporated}

Considering that in nature microorganisms develop in more or less complex communities, ${ }^{35}$ the algaecide capacity of paints formulated with the natural compound was evaluated against different isolated taxa and also against $\mathrm{R}$ and $\mathrm{P}$ communities. The results are shown in Fig. 5. It can be observed that the development of algal biomass only occurred in the control samples (paint without biocide). It has been reported that in water-based and acrylic paints complex phototrophic biofilms (algae and cyanobacteria) can develop. ${ }^{36}$ Besides, it is known that cellulosic components can act as nutrients for microorganisms that produce cellulase enzyme ${ }^{36}$ and that inorganic materials leached from the paint, such as phosphates, can aid algal growth on the surface. ${ }^{37}$ Despite this, in our experiments a total inhibition of growth of all the algae assayed was achieved when the natural compounds were incorporated in the paint formulation, indicating that these compounds could act as effective algaecides to control algal development on painted walls. 


\section{Conclusions}

Four organic compounds, which can be obtained from plants, were assayed for their algaecide activity on different algae taxa. While anisole did not show any algaecide effect, guaiacol, eugenol, and thymol presented good algaecide properties. When the later compounds were incorporated into a waterborne paint, no algal growth was observed. Thus, from our results, we may conclude that guaiacol, eugenol, and thymol are promising algaecides which may be used in the formulation of exterior waterborne paints to avoid paint deterioration as a consequence of biofilm formation. At the same time, the use of these more environmentally friendly biocides will help in controlling pollution of urban waters due to paint leaching, reducing adverse effects on the environment and human health.

Field-scale experiments will be performed to evaluate the performance of the formulated paints with the natural compounds under real environmental conditions.

Acknowledgments The authors are grateful to the National University of La Plata Project 11/I201, CONICET PIP No. 00314 and CICBA 833/14 for the Grants received to finance this work.

\section{References}

1. Gaylarde, PM, Gaylarde, CC, "Algae and Cyanobacteria on Painted Buildings in Latin America." Int. Biodeter. Biodegrad., 46 93-97 (2000)

2. Gaylarde, CC, Morton, LHG, Loh, K, Shirakawa, MA, "Biodeterioration of External Architectural Paint Films-A Review." Int. Biodeterior. Biodegrad., 65 1189-1198 (2011)

3. O'Neill, TB, "Succession and Interrelationships of Microorganisms on Painted Surfaces." Int. Biodeterior., 24 373-379 (1988)

4. Barberousse, H, Lombardo, RJ, Tell, G, Couté, A, "Factors Involved in the Colonisation of Building Façades by Algae and Cyanobacteria in France." Biofouling, 22 69-77 (2006)

5. Gómez de Saravia, S, Battistoni, P, Guiamet, P, "Phototrophic Biofilms on Exterior Brick Substrate." Res. Rev. BioSci., 11 (2) 10 (2016)

6. Bold, H, Wynne, M, Introduction to the Algae. Prentice Hall Inc, Upper Saddle River (1978)

7. Saiz-Jimenez, C, "Biodeterioration vs Biodegradation: the Role of Microorganisms in the Removal of Pollutants Deposited on Historic Buildings." Int. Biodeterior. Biodegrad., 40 225-232 (1997)

8. Sasso, S, Miller, AZ, Rogerio-Candelera, MA, Cubero, B, Coutinho, ML, Scrano, L, Bufo, S, "Potential of Natural Biocides for Biocontrolling Phototrophic Colonization on Limestone." Int. Biodeterior. Biodegrad., 107 102-110 (2016)

9. Cappitelli, F, Salvadori, O, Albanese, D, Villa, F, Sorlini, C, "Cyanobacteria Cause Black Staining of the National Museum of the American Indian Building (Washington, DC, USA)." Biofouling, 28 257-266 (2012)
10. Burkhardt, M, Zuleeg, S, Vonbank, R, Schmid, P, Hean, S, Lamani, X, Bester, K, Boller, M, "Leaching of Additives from Construction Materials to Urban Storm Water Runoff." Wat. Sci. Technol., 63 1974-1982 (2011)

11. Bollmann, U, Vollertsen, J, Carmeliet, J, Bester, K, "Dynamics of Biocide Emissions from Buildings in a Suburban Stormwater Catchment-Concentrations, Mass Loads and Emission Processes." Wat. Res., 56 66-76 (2014)

12. Burkhardt, M, Kupper, T, Hean, S, Haag, R, Schmid, P, Kohler, M, Boller, M, "Biocides Used in Building Materials and Their Leaching Behavior to Sewer Systems." Wat. Sci. Technol., 56 63-67 (2007)

13. Jančula, D, Maršalek, B, "Critical Review of Actually Available Chemical Compounds for Prevention and Management of Cyanobacterial Blooms." Chemosphere, 85 1415$1422(2011)$

14. Borrego, S, Gómez de Saravia, S, Valdes, O, Vivar, I, Battistoni, P, Guiamet, P, "Biocidal Activity of Two Essential Oils on Fungi that Cause Degradation of Paper Documents." IJCS, 7 369-380 (2016)

15. Shao, J, Li, R, Lepo, JE, Gu, J, "Potential for Control of Harmful Cyanobacterial Blooms Using Biologically Derived Substances: Problems and Prospects." J. Environ. Manag., 125 149-155 (2013)

16. Cimanga, K, Kambu, K, Tona, L, Apers, S, Bruyne, T, Hermans, N, Totte, J, Pieters, L, Vlietinck, A, "Correlation Between Chemical Composition and Antibacterial Activity of Essential Oils of Some Aromatic Medicinal Plants Growing in the Democratic Republic of Congo." $J$. Ethnopharmacol., 79 213-220 (2002)

17. Dalleau, S, Cateau, E, Berges, T, Berjeaud, J, Imbert, C, "In Vitro Activity of Terpenes Against Candida Biofilms." Int. J. Antimicrob. Agents, 6 572-576 (2008)

18. Rojo, L, Barcenilla, J, Vázquez, B, González, R, San Román, $\mathrm{J}$, "Intrinsically Antibacterial Materials Based on Polymeric Derivatives of Eugenol for Biomedical Applications." Biomacromolecules, 9 2530-2535 (2008)

19. Liu, H, Lepoittevin, B, Roddier, C, Guerineau, V, Bech, L, Herry, J, Bellon-Fontaine, M, Roger, P, "Facile Synthesis and Promising Antibacterial Properties of a New GuaiacolBased Polymer.' Polymer, 52 1908-1916 (2011)

20. Wattanasatcha, A, Rengpipat, S, Wanichwecharungruang, S, "Thymol Nanospheres as an Effective Anti-bacterial Agent." Int. J. Pharmacol., 434 360-365 (2012)

21. Pérez, M, García, M, Blustein, G, "Evaluation of Low Copper Content Antifouling Paints Containing Natural Phenolic Compounds as Bioactive Additives." Mar. Environ. Res., 109 177-184 (2015)

22. Rippka, R, Deruelles, J, Waterbury, JB, Herdman, M, Stanier, RY, "Generic Assignments, Strain Histories and Properties of Pure Cultures of Cyanobacteria." J. Gen. Microbiol., 111 1-61 (1979)

23. Komárek, J, Fott, B, "Chlorophyceae, Ordnung Chlorococcales". In: Elster H.-J-, Ohle W. (eds.) Die Binnengewässer. Band 16, 7 Teil, 1 Hälfte. Schweizerbart'sche Verlagsbuchhandlung, Stuttgart (1983)

24. Komárek, J, Anagnostidis, K, "Cyanoprokaryota Part 1 Chroococcales." In: Ettl, H, Gärtner, G, Heynig H, Mollehauer (eds.) Sü $\beta$ wasserflora von Mitteleuropa 19/1. G. Fischer. Jena, Stuttgart, Lübeck, Ulm (2000).

25. Komárek, J, Anagnostidis, K, "Cyanoprokaryota Part 2 Oscillatoriales." In: Büdel, B, Krienitz, L, Gärtner, G, Schagerl, M (eds.) Sü $\beta$ wasserflora von Mitteleuropa 19/2. Elsevier, München (2005).

26. Delespaul, Q, de Billerbeck, VG, Roques, CG, Michel, G, Marquier-Viñuales, C, Bessière, JM, "The Antifungal Activ- 
ity of Essential Oils as Determined by Different Screening Methods." JEOR, 12 256-266 (2000)

27. Zucconi, L, Gagliardi, M, Isola, D, Onofri, S, Andaloro, MC, Pelosi, C, Pogliani, P, Selbmann, L, "Biodeterioration Agents Dwelling in or on the Wall Paintings of the Holy Saviour's Cave (Vallerano, Italy)." Int. Biodeterior. Biodegrad., 70 40-46 (2012)

28. Kordali, S, Cakir, A, Ozer, H, Cakmakci, R, Esdek, M, Mete, E, "Antifungal, Phytotoxic and Insecticidal Properties of Essential Oil Isolated from Turkish Origanum acutidens and Its Three Components, Carvacrol, Thymol and p-Cymene." Biores. Technol., 99 8788-8795 (2008)

29. Trombetta, D, Castelli, F, Sarpietro, MG, Venuti, V, Cristani, M, Daniele, C, Saija, A, Mazzanti, G, Bisignano, G, "Mechanisms of Antibacterial Action of Three Monoterpenes." Antimicrob. Agents Chemother., 49 2474-2478 (2005)

30. Nanasombat, S, Lohasupthawee, P, "Antibacterial Activity of Crude Ethanolic Extracts and Essential Oils of Spices Against Salmonella and Other Enterobacteria." KMITLSTJ, 5 527-538 (2005)

31. Louie, G, Baiga, T, Bowman, M, Koeduka, T, Taylor, J, Spassova, S, Pichersky, E, Noel, J, "Structure and Reaction Mechanism of Basil Eugenol Synthase." PLoS ONE, 2 e993 (2007)
32. Darvishi, E, Omidi, M, Bushehri, A, Golshani, A, Smith, M, "The Antifungal Eugenol Perturbs Dual Aromatic and Branched-Chain Amino Acid Permeases in the Cytoplasmic Membrane of Yeast." PLoS ONE, 8 e76028 (2013)

33. Tang, KH, Wee, YC, Ho, KK, "Laboratory Evaluation of Biocides for the Control of Trentepohlia odorata." Int. Biodeterior., 21 5-10 (1985)

34. Rana, IS, Rana, AS, Rajak, RC, "Evaluation of Antifungal Activity in Essential Oil of the Syzygium aromaticum (L.) by Extraction, Purification and Analysis of Its Main Component Eugenol." Braz. J. Microbiol., 42 1269-1277 (2011)

35. Sand, W, "Microbial Mechanisms of Deterioration of Inorganic Substrates-A General Mechanistic Overview." Int. Biodeterior. Biodegrad., 40 183-190 (1997)

36. Morton, LHG, Gaylarde, CC, "Deteriogenic Biofilms on Buildings and Their Control." Biofouling, 14 59-74 (1999)

37. Allsopp D, Seal K, Gaylarde C, "Introduction to Biodeterioration," Chap. 3. 261. In: Biodeterioration of Refined and Processed Materials: Paints, second ed., vol 262, pp. 78-85. Cambridge University Press, Cambridge (2004).

38. Kappock PS, "Biocides: Wet State and Dry Film." Chap. 8. In: Florio, JJ, Miller, DJ (eds.) Handbook of Coating Additives, p. 271. Marcel Dekker, New York (2004). 